\title{
DIMENSIONING THE NAVIGATIONAL SAFETY IN MARITIME TRANSPORT
}

\section{WYMIAROWANIE BEZPIECZEŃSTWA NAWIGACYJNEGO W TRANSPORCIE MORSKIM}

\author{
Leszek Smolarek \\ Akademia Morska w Gdyni, Wydział Nawigacyjny \\ ul. Morska 81-87, 81-225 Gdynia \\ leszsmol@am.gdynia.pl
}

\begin{abstract}
In the paper some problems of quantitive description of traffic safety in maritime transport are presented. Basic definitions and a stochastic approach to concept of traffic safety in transport are given. The stochastic method of dimensioning traffic safety, useful in short-term traffic control, is proposed.
\end{abstract}

Keywords: safety dimensioning, traffic control stochastic models, safety in sea transport

Streszczenie. Na bezpieczeństwo nawigacyjne $w$ transporcie morskim wptywaja zarówno zewnętrzne jak $i$ wewnętrzne czynniki działające na statek. Dlatego szacując bezpieczeństwo nawigacyjne należy uwzględnić zależności od sytuacji nawigacyjnej, warunków hydrologiczno-meteorologicznych, parametrów eksploatacyjno-technicznych statku, sprawności urządzeń i wyposażenia na statku oraz postępowania zatogi. Istniejace metody i kryteria do oceny sytuacji nawigacyjnej takie jak np. parametr CPA, TCPA, domena statku, obszary kolizyjne pozwalaja na określenie ryzyka $w$ odniesieniu do bezpieczeństwa statku poprzez przyporzadkowanie sytuacji nawigacyjnej liczby rzeczywistej. Prowadzi to do określenia bezpieczeństwa $w$ ujęciu statycznym. Bezpieczeństwo nawigacyjne w ujęciu dynamicznym wymaga badania zmiennych $w$ czasie geometrycznych zależności pomiędzy jednostki ptywajacymi i obiektami stwarzającymi zagrożenie nawigacyjne kolizja. Koncepcja ruchu nadzorowanego tzw. autostrad morskich wymaga opracowania metod oceny bezpieczeństwa nawigacyjnego uwzględniających zmienność $w$ czasie sytuacji nawigacyjnej. Jest to istotne $w$ przypadku procesu identyfikacji sytuacji niebezpiecznej, a także ze względu na zmniejszenie ryzyka kolizyjnego. W artykule przedstawiono model dynamicznej oceny ilościowej bezpieczeństwa nawigacyjnego wykorzystujacy dwuwymiarowe pola losowe.

Stowa kluczowe: wymiarowanie bezpieczeństwa, modele stochastyczne ruchu, bezpieczeństwo $w$ transporcie morskim 


\section{General Introduction}

The safety of navigation in the maritime is under influence of both external and internal factors acting on the ship. Therefore, assessing the safety of navigation should be included, depending on the situation of navigational, hydro-meteorological conditions, technical parameters of the vessel, the efficiency of appliances and equipment on board and the conduct of the crew, (Pietrzykowski Z., Chomski J., 2003,).

Existing methods and criteria to assess a situation such as a navigational parameter of the CPA, TCPA, the domain of the vessel, the areas of conflict possible to determine the risk for the safety of the vessel through the assignment of a navigational position of a real number, (Uriasz J., 2006 ). This leads to define safety in terms of static.

Safety of navigation in a dynamic test requires a time-varying geometric relationship between the body and floating objects presenting a navigational hazard of collision.

The concept of the so-called supervised traffic, Motorways of the Sea requires the development of safety assessment methodologies take into account the variability of the navigation during the navigational situation, (Skorupski J., 2003). This is important for the identification of dangerous situations, and also because of the reduction in the risk conflict.

The paper presents a dynamic model of quantitative evaluation of the safety navigation using two-dimensional random field.

Quantitative research can include:

- the generation of models,

- the development of methods for measurement

- experimental control of variables

- collection, modeling and analysis of empirical data

- evaluation of results.

\section{Dimensioning in Maritime Transportation}

Ship accidents at sea have and will occur despite the use of high-tech equipment so it's necessary to built models which can help in dimensioning traffic safety at maritime transport.

Since 1959, a whole series of international measures, such as ships' routing measures, traffic separation schemes; ship reporting systems; and vessel traffic services, made a significant contribution to the safety of navigation. Systems, mandatory and recommended, have been established on most of the world's major shipping routes, within a reduction on the number of collisions. But still a number of collisions have occurred recently of which 
one of the causal factors has been a result of a seamanship non proper look out.

The ship safety at supervised traffic requires continuous identification of the navigational situation.

The problem of risk measuring for a traffic situation may be divided into two main stages:

- modeling the joint evolution of traffic lane width according to a single ship;

- modeling the hazard map by using traffic and navigational situation.

Static safety is described by a random variable which mapped the traffic and navigational situation a real number as a measure of safety.

Safety assessment of the traffic situation can be made by examining the relative positions of vessel's domains. A limitation is the fact that most domain of the vessel is used to describe the preferences of a navigator and subjective risk acceptance and not to define the recommendations dealing with the situations of conflict.

The following algorithm for evaluation of safety can be used:

- determining of random maps taking into account the situation of navigational hazards,

- isolating potential traffic corridors,

- identifying potential areas of conflict,

- determining the relative weights for each area of conflict and mutual interactions of ships,

- determining the conditional's safety levels for analyzed area (mobility navigation system) and the variant of traffic situation,

- determining the traffic options for the evolution of the situation and their cumulative probability distribution (using the expected values to determine the position of individual vessels)

- determination of aggregate safety factor (using the total probability formula).

\subsection{The traffic lane width according to a single ship}

The width of the traffic lane depends on factors such as, (Gucma S., 2001): navigational:

- error rate evaluation of current speed,

- ship Speer,

- ship course terror,

- error to maintain the ship on course,

- error for determining the angle of drift; 
human factor:

- navigator's response time according to a divergence of ship from the track axis, (analysis and issue commands),

- steersman's response time from heating to execute the command;

technical and operational ship parameters:

- inertia time exchange rate depends on the ship's maneuverability, size, loading condition, meteorological conditions and the rudder angle of deflection

- ship lateral airflow,

- underwater cross-sectional area of longitudinal section of the hull,

- wind speed,

- wind angle Exchange,

- drift angle,

- maximum ship length

- width of the ship.

The problem of modeling the traffic lane width of a single ship may be done by modeling of the joint evolution of main factors $\left(\mathrm{X}_{1}, \ldots, \mathrm{X}_{\mathrm{n})}\right.$ affecting lane width during a specified time period.

The use of copula function allows us to overcome the issue of estimating the multivariate distribution function by splitting it into two parts:

- determine the margins $F_{1}, \ldots, F_{n}$, which represent the distribution of each random factor, and estimate their parameters, fitting the available data by choosing statistical methods,

- determine the dependence structure of the random variables $X_{1}, \ldots, X_{n}$, specifying a meaningful copula function.

The Copula function for two factors can be described by, (Sklar, A., 1996)

$$
C\left(x_{1}, x_{2}\right)=x_{1} \cdot x_{2} \cdot\left\{1+\gamma\left[1-x_{1}\right] \cdot\left[1-x_{2}\right]\right\}
$$

As the conformity criterion of modeled random vectors $\left[X_{1}, X_{2}\right]$ the equality of their means, variances and correlation coefficient can be used. In this case joint probability density function, which used Copula function and one dimensional distribution, is described by

$$
\left.h(x, y)=f_{X_{1}}(x) \cdot f_{X_{2}}(y) \cdot\left\{1+\gamma \mid 1-2 F_{X_{1}}(x)\right] \cdot\left[1-2 F_{X_{2}}(y)\right]\right\}
$$

where parameter $\gamma$ is given by formula

$$
\gamma=\rho_{X_{1} X_{2}} \cdot \frac{\delta_{X_{1}}}{\left(\bar{X}_{1}+2 \int_{0}^{x_{0}} x f_{X_{1}}(x) F_{X_{1}}(x) d x\right)} \cdot \frac{\delta_{X_{2}}}{\left(\bar{X}_{2}+2 \int_{1}^{y_{0}} y f_{X_{2}}(y) F_{X_{2}}(y) d \kappa\right)}
$$




\subsection{Rasch Model}

The Rasch Model (RM), due to the work of Rost (1990), contains both latent trait and latent class variables, (Alagumalai, S., Curtis, D.D. \& Hungi, N., 2005). We assume that the RM does not hold for the entire population, but does so within subpopulations of individuals which are not known before hand. The probability that the ship $\mathrm{i}$ react at collision situation $\mathrm{j}$ correctly is:

$$
P\left(X_{i j}=1 \mid \theta_{i}, \phi_{i}, \beta_{j}\right)=\frac{\exp \left(\theta_{i}-\beta_{\phi_{i} j}\right)}{1+\exp \left(\theta_{i}-\beta_{\phi_{i} j}\right)}
$$

Where $\theta_{\mathrm{i}}$ is the i's ship ability, $\varphi_{\mathrm{i}}$ indicates which latent group the ship $\mathrm{i}$ belongs to, and $\beta_{\phi_{i} j}$ denotes the situation j's difficulty which depends on group variable $\varphi$.

Suppose there are $G$ classes, number of classes is not less than 2, the unconditional probability that the ship $i$ react at collision situation $j$ correctly is:

$$
P\left(X_{i j}=1 \mid \theta_{i}, \beta_{\phi_{i j}}\right)=\sum_{g=1}^{G} \pi_{g} \frac{\exp \left(\theta_{i}-\beta_{\phi_{i j}}\right)}{1+\exp \left(\theta_{i}-\beta_{\phi_{i j}}\right)}
$$

where

- $\pi_{g}$ - probability that the ship belongs to class $g$,

- $\sum_{g} \pi_{g}=1$, and $0<\pi_{g}<1$,

- $\sum_{j} \beta_{j}=0$, or $\mathrm{E}(\theta)=0$ for all classes.

\subsection{Dynamic Hazard Map}

Dynamic hazard map is based on grid of probabilities. The grid of probabilities $q_{i j}(t)$ is introduced for the investigated scenario for the traffic navigational situation. It is determined by the measure of occupancy of individual grid cells, (Smolarek L., Guze S, 2009). The scenarios take into account the velocity vectors of all ships in the relevant area.

The occupancy measure is given by the following form.

$$
q_{i j}(t)=q(i, t) \cdot q(j, t) \text {. }
$$

where $i, j \in N, t \in<0, \infty)$, and the probability measures $q(i, t)$ and $q(j, t)$ can be given by any well-known density function.

In particular case, when it is assumed that these measures are given by beta and gamma density function, the formulae for the cell $\mathrm{e}_{\mathrm{ij}}$ is following form: 


$$
\begin{gathered}
q_{i j}(t)=\iint_{\theta_{i j}} \frac{x^{\alpha_{i}-1}(1-x)^{\beta_{i}-1}}{B\left(\alpha_{i}, \beta_{i}\right)} \frac{e^{-\left(\frac{y}{\beta_{j}(t)}\right)}}{\Gamma(\alpha(t)) \beta_{j}(t)^{\alpha(t)}} d x d y, \\
\Gamma(y)=\int_{0}^{+\infty} z^{y-1} e^{-z} d z \quad B(\alpha, \beta)=\frac{\Gamma(\alpha+\beta)}{\Gamma(\alpha) \Gamma(\beta)} \\
i \in I, j \in N, \alpha(t)>0, \beta(t)>0, \lambda(t)>0, t \in 0, \infty)
\end{gathered}
$$

where

From above formulas the grid of occupancy are calculated in considered navigational situation and we get random maps for the given moment of time (Figure 1).
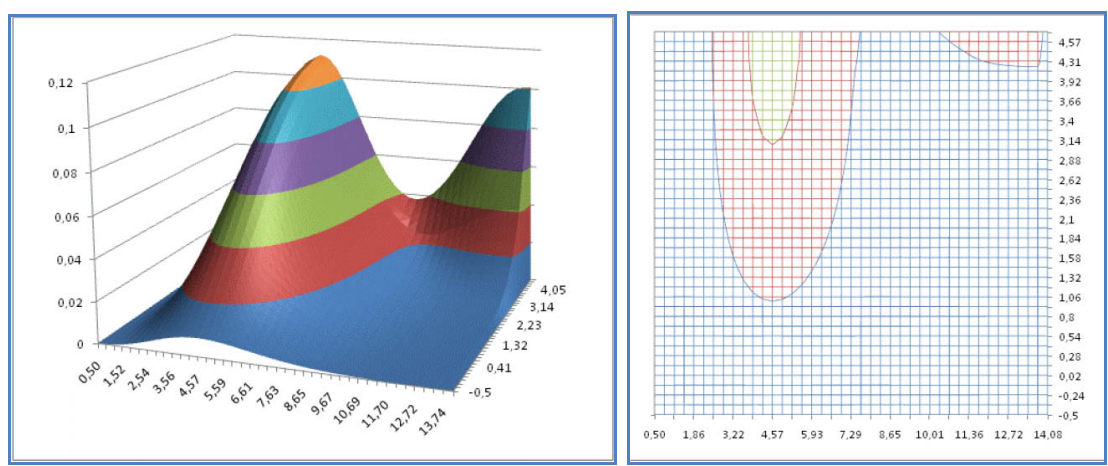

Fig. 1 Example of the grid of two ships and the density functions $\boldsymbol{q}_{i j}(\boldsymbol{t})$ given by (7).

Dynamic safety is the stochastic process which is described, for fixed time moment $t_{0}$ by a random variable defining static safety for a given traffic and navigational situation.

\section{Hazard's importance estimation}

The Tail Value at Risk (TailVaR $\alpha$ ) is defined as the average of all collision scenarios over the $100 \cdot \alpha$ th percentile, where $\alpha$ is a selected probability level, such as $0.99^{1}$. This measure is larger than the Value at Risk for the same probability level because it is the average of all collision events that are over the Value at Risk, i.e. the 100· $\alpha$ th percentile, (Smolarek L., Guze S, 2009).

1 REPORT TO AMERICAN ACADEMY OF ACTUARIES INDEX SECURITIZATION TASK FORCE by CASUALTY ACTUARIAL SOCIETY VALUATION, FINANCE AND INVESTMENTS COMMITTEE, Harvey A. Sherman. 
The Standard Deviation risk measure, for selected constant $\mathrm{K}(\mathrm{K}=3)$, is defined as:

$$
\text { StdDev }_{3}=E(\text { capsizing })+3 \cdot \operatorname{StdDev}(\text { capsizing }) \text {. }
$$

These risk measures can be applied after (Post) and before (Pre) changes of the traffic at area system and the risk reduction measures is defined as follows:

$$
\begin{gathered}
\text { TailVaR }_{\alpha} \text { reduction }=1-\frac{\text { PostTailVaR }_{\alpha}}{\operatorname{Pr} e \text { TailVaR }_{\alpha}}, \\
\text { StdDev }{ }_{3} \text { reduction }=1-\frac{\text { PostStdDev }_{3}}{\operatorname{Pr} e S t d D e v_{3}} .
\end{gathered}
$$

The standard deviation is often used to measure the risk of dynamic systems. The standard deviation is a measure of volatility it means that if system safety parameters more vary from the average return than the more volatile is the area system safety.

The Tail Value at Risk reflects both the probability and magnitude of the collision probability. This measure is looking at one side of the possible outcomes.

The stationarity of a system means that:

- in the statistical sense - the mean, variance, skew and kurtosis of the system parameter distributions are taken to be stable through time;

- in the dynamical sense - the forms of the equations that describe a system's dynamics are assumed to be constant through time.

\section{The regenerative model}

Suppose that $\xi=\xi(t) ; t \geq 0)$ is a stochastic process evolving on some state space $\mathrm{S}$.

Definition $1 \mathrm{We}$ say that $\xi(\mathrm{t})$ is a regenerative stochastic process if there exists a boundary sequence with the property that the induced cycles are independent identically distributed

The same definition may be applied to processes $\xi_{n}\left(\xi_{n} ; n \geq 0\right)$ in discrete time by simply taking $\xi(\mathrm{t})=\xi_{[\mathrm{t}]}$.

Let $\mathrm{f}: \mathrm{S} \rightarrow \mathrm{R}$ be a real-valued function, $y_{i}=\int_{t_{i-1}}^{t_{i}} f(\xi(u)) d u, \tau_{i}=t_{i}-t_{i-1}$, for $\mathrm{i} \geq 1$.

Theorem 1 Suppose that $\xi$ is a regenerative process and $\mathrm{f}: \mathrm{S} \rightarrow \mathrm{R}$.

1. If $\mathrm{E}\left(\mathrm{y}_{1}|\mathrm{f}|+\tau_{1} /<\infty\right.$, then $\alpha(\mathrm{t}) \rightarrow \alpha$ a.s., as $\mathrm{t} \rightarrow \infty$, where_ $\alpha=\mathrm{EY}(\mathrm{f}) / \mathrm{E} \tau_{1}$.

2. If $\mathrm{E}\left(\mathrm{Y}_{1}(|\mathrm{f}|)^{2}+\tau_{1}^{2}<\infty\right.$, then $\sqrt{t}(\alpha(t)-\alpha) \Rightarrow \sigma N(0,1)$ 
as $\mathrm{t} \rightarrow \infty$, where $\Rightarrow$ denotes weak convergence, and $\mathrm{N}(0,1)$ is a standard normal random variable, (Andrews J.D., Moss T.R., 1993).

The safety level of the analyzed area, at time $t$, can be modeled by a regenerative process if it can be divided into mutually independent cycles, (Smolarek L., 2009). Every time point, when the safety level is crossing up the prescribed acceptable level of safety, is called the regeneration time.

For each cycle the partial models such as:

- the traffic lane width according to a single ship

- rasch model

- dynamic hazard map

could be used to evaluate the area safety factor.

The time points between the cycles are called the regeneration points. As regeneration points we shall use the acceptable level of safety crossing up times. The definition of the regenerative process can be understood more generally - the first cycle can start later, not necessarily in the point of regeneration.

Let us denote by: $t_{i}$ - the length of the $i$-th cycle of the regenerative model, $y_{i}$ - the indicator function of the acceptable level of safety crossing up associated to the $\mathrm{i}$-th cycle of the regenerative model. This gives us identically distributed variables $t_{1}, t_{2}, . .,-$ and associated $y_{1}, y_{2}, \ldots$ The pairs $\left(t_{i}, y_{i}\right)$ are mutually independent and identically distributed (except perhaps for $\mathrm{i}=1$ ). By using the central limit theorem we get the following results for the asymptotic distribution of the number of the acceptable level of safety crossing up:

Let $N_{t}$ be the number of cycles of the regenerative model until time t, $E t_{i}=$ $E_{t}$ the expected value of the length of the i-th cycle of the regenerative model and $\mathrm{Ew}=\mathrm{E} w_{i}=1$. Furthermore, $\operatorname{Var}\left(\mathrm{t}_{\mathrm{i}}\right)=\mathrm{s}^{2}$ (assumed finite) for all $\mathrm{i} \in$ N. Then asymptotically

$$
\lim _{t \rightarrow \infty} \frac{N_{t}-\frac{1}{E_{t}}}{s \sqrt{\left(\frac{1}{E_{t}}\right)^{3}}}=N(0,1)
$$

\section{Conclusions}

Safety of crew and passengers who are participants in the maritime transport process is one of the priority criteria for this process safety evaluation.

The traffic process safety is affected by many factors such as

- efficiency and reliability of the vessel as a means of transportation, 
- failure of seaman ships and the people in charge of supervising the process of sea transport,

- the traffic organization and the rules

- hydro meteorological parameters

Safety in maritime transport can be analyzed and assessed both at the micro level (safety of the ship, the safety of navigation in a specific situation mobility) as well as in terms of macro models (evaluation over time).

Vessel safety assessment carried out upon IMO standards allows theoretical estimating of safety without actual vessel conditions details and condition of crew.

The goal for the sea and inland waterways states that the infrastructure should be developed to create the 'motorways of the seas'. Especially the work processes need to be made clearer, and the working rules should be simplified regarding all of the participants involved, (Kari Wihlman, 2009.). One way to assess the traffic safety approximation is analysis of the potentially conflicting situation.

The sensitivity of the safety to a particular input parameter can be used to estimate the effect of parameter changes on the model result, without necessitating a full model solution for each parameter change. Several measures have been defined to assess component importance, in an attempt to capture the combined effect of environment and probabilistic contributions to system safety from basic parameters. The importance measure, which is defined as the partial derivative, attributable to Birnbaum, has remained popular, (Frank P.M.,1978).

For more sophisticated cognitive modeling is necessary to model numerous failure modes or represent complex interdependencies between human error sources, ship route, ship technical and exploitations parameters.

\section{REFERENCES}

1. Alagumalai, S., Curtis, D.D. \& Hungi, N. (2005). Applied Rasch Measurement: A book of exemplars. Springer-Kluwer.

2. Andrews J.D., Moss T.R., Reliability and risk assessment, Longman Scientific and Technical, Essex, 1993.

3. Frank P.M., Introduction to system sensitivity, Academic Press, 1978.

4. Gucma S.: Inżynieria ruchu morskiego. Okrętownictwo i Żegluga, Gdańsk. 2001

5. Kari Wihlman, The traffic safety challenges facing the new transport administration, Northern Dimension \& Traffic Safety Seminar 7th September 2009. 
6. Pietrzykowski Z., Chomski J., A Navigator Decision Support System in Planning a Safe Trajectory, 4th IAMU General Assembly, 2003, Alexandria

7. Sklar, A., Random variables, distribution functions, and copulas - a personal look backward and forward, in Distributions with Fixed Marginals and Related Topics, ed. By L.Rüschendorff, B. Schweizer and M. Taylor, pp. 1-14. Institute of Mathematical Statistics, Hayward, CA. (1996).

8. Skorupski J. Traffic Safety Dimensioning, Archives of Transport vol. XV, No.3, Warszawa 2003.

9. Smolarek L., Finite Discrete Markov Model of Ship Safety, Marine Navigation and Safety of Sea Transport, Balkema Book 2009.

10. Smolarek L., Guze S.: Ocena czułości modeli operacyjnoeksploatacyjnych. Problemy Eksploatacji/Maintenance Problems, Vol. 2, No. 4, 2009, 105-114.

11. Smolarek L., Guze S.: Modelling the ship safety on waterway according to navigational signs reliability. Electronic Journal Reliability \& Risk Analysis: Theory \& Application, Vol. 2, No. 4, 2009, 131-140.

12. Uriasz J., Shape and Dimension of Ship's Safety Zones, Zeszyty Naukowe Akademii Morskiej w szczecinie, No. 11 (83), 2006, pp. 343356.

dr hab. Smolarek Leszek, Gdynia Maritime University, Gdynia, Professor extraordinarius at the Faculty of Navigation. He has published more than 30 books, reports and papers in journals and conference proceedings. Specialization: applied statistics, reliability, transport safety. 